\title{
https://doi.org/10.1038/s41467-021-20927-9
}

\section{Publisher Correction: Enhancer remodeling promotes tumor-initiating activity in NRF2- activated non-small cell lung cancers}

Keito Okazaki, Hayato Anzawa (1), Zun Liu, Nao Ota, Hiroshi Kitamura, Yoshiaki Onodera,

Md. Morshedul Alam (1), Daisuke Matsumaru (1), Takuma Suzuki, Fumiki Katsuoka, Shu Tadaka, Ikuko Motoike, Mika Watanabe, Kazuki Hayasaka (D), Akira Sakurada, Yoshinori Okada, Masayuki Yamamoto (D), Takashi Suzuki, Kengo Kinoshita (1), Hiroki Sekine (i) \& Hozumi Motohashi (D)

Correction to: Nature Communications https://doi.org/10.1038/s41467-020-19593-0, published online 20 November 2020.

This Article contained an error in Fig. 8. In Fig. 8h multiple white and blue bars denoting CEBPB were present in the histogram.

This has now been corrected in the PDF and HTML versions of the Article.

Published online: 15 January 2021

\footnotetext{
(c) Open Access This article is licensed under a Creative Commons Attribution 4.0 International License, which permits use, sharing, adaptation, distribution and reproduction in any medium or format, as long as you give appropriate credit to the original author(s) and the source, provide a link to the Creative Commons license, and indicate if changes were made. The images or other third party material in this article are included in the article's Creative Commons license, unless indicated otherwise in a credit

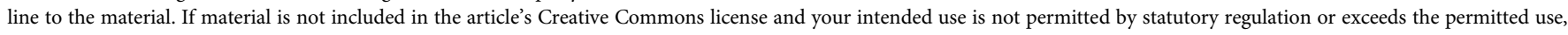
you will need to obtain permission directly from the copyright holder. To view a copy of this license, visit http://creativecommons.org/licenses/by/4.0/.
}

(C) The Author(s) 2021 